\title{
2Dp 02
}

\section{障害の種類・程度と道具・生活空間との適応に関する研究- 1} 一脊髄損佰者の障害程度と出入口-

\author{
○御手洗謙二、藤家 謷（総合せき損センター・医用工学研究室） \\ 古賀 唯夫 (九州芸術工科大学・工業設計学科) \\ Research on the Adapted for Living Facilities and Space for Disabled \\ - Part 1 : Doors for Spinal injuries - \\ K. Mitarai, K. Fuj i ie(Spinal Injuries Center, Dept. of Reh. Eng. ) \\ T. Koga(Kyushu Institute of Design, Dept. of ID)
}

\section{1. 目的}

肢体障害者においては障害の種類や程度によ り身体の活動能力が大きく異なっている。近年 公共施設をはじめとして車いすを考慮した道具 や生活空間の整備が進んでいるが、障害の程度 差を考慮したものは少なく、図 1 のエリアAに 分類される上肢健常で体幹の安定も良い車いす 使用者を主に対象として考慮されたものがほと んどである。しかしリ八医療の進展により障害 者の自立レベルも向上しており、より重度の障 害者また障害の種類や個人差による動作特性を 考慮した整備が必要であろう。

このため本研究では重度障害者の種々の動作 特性を把握し、障害程度別の道具・生活空間へ の適応に関して考察することを目的とし、今回 は春髄損傷者を対象として、出入口の通り抜け における動作特性を車いすの使い方や扉の開閉 動作、開屝力、また制限のない空間でのアプロ 一チ方法等を中心に検討を行うものである。

\section{2. 測定方法}

(1)被検者：平坦地で車いすの自力走行が可能 な脊髄損傷者（C 5〜 T 10）13名で行った。

(2)動作の記録：実験室内にドアフレームを設 置し11種類の交換ドアパーツを作成した。今回 はその内の 2 種類（引き戸：開口部巾 $800 \mathrm{~mm}$, 開 き戸：巾 $800 \mathrm{~mm}$ )を使用して、車いすでの扉の開 閉および通り抜け動作の測定を行った。記録に は上方・側方からのビデオ及びスチルカメラに よる撮影の他、三次元動作解析システム〔オク スフォードメトリクス社:VICON]を使用した。

(3)開屝力の測定：車いすを使用してドアを開
ける時の最大操作力（開屝力）をロードセル〔 共和電業, LU-50KE〕及びストレインアンプ〔日 本電気三栄，6M47-8〕を用いて測定した。

\section{3 . 結 果}

車いすでのドアへのアプローチや開閉、通り 抜け動作には残存レベルの違い等により種々の 相違があり、写真やビデオ等での観察により動 作に関わる要因を抽出した（図 2 ）。

レベルによる動作の主な相違点としては以下 が見られた。ドアへのアプローチでは脊髄損傷 者は出入り動作を効果的に行うため車いすのブ レーキは使用せず、他方の手で車いすや体幹の コントロールを行いながら扉を開けるケースが 多くドアハンドルから離れて位置している（図 3）。他方頸髄損傷者では何度か車いすを移動 させることになるが、力を最大限発揮できるよ うドアハンドルに近接した位置につけブレーキ をかけて操作している（図 4）。

最大開扉力の測定結果を図 5 ・6 に示すが、 ブレーキをかけていない脊髄損傷者ではブレー キをかけた頸䯣損傷者に較べ同程度か小さくな る傾向にあり、重度の頸髄損傷者でさらに小さ くなっている。開扉力では障害レベルによる力 や操作方法の相違の他、ドア面に対する車いす の相対角度、距離や床面との摩擦係数等が要因 として考えられた。

その他にも、重度の障害者では車いすの移動 やドア開口部のスペース等に種々の差異が見ら れ、円滑に出入り動作を行うには現在の一般的 な基準では不十分であり、より適切な対応が必 要である。 


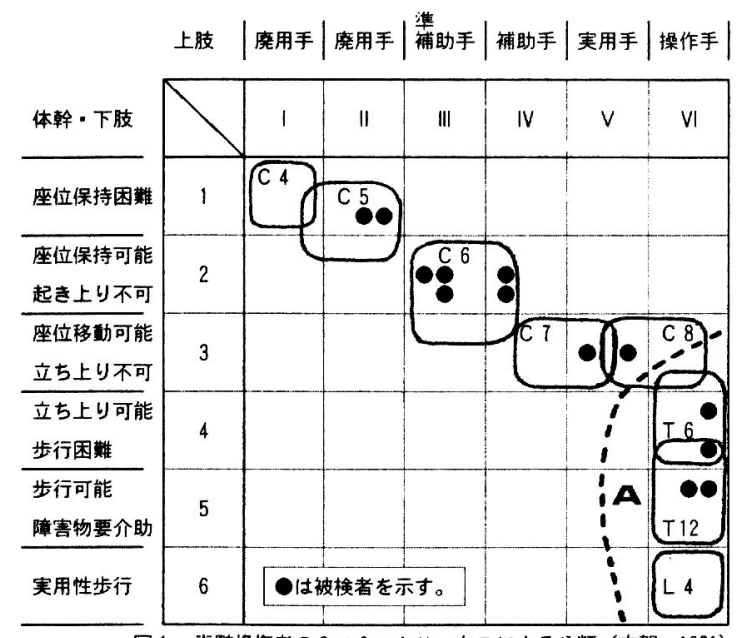

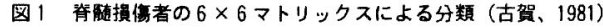

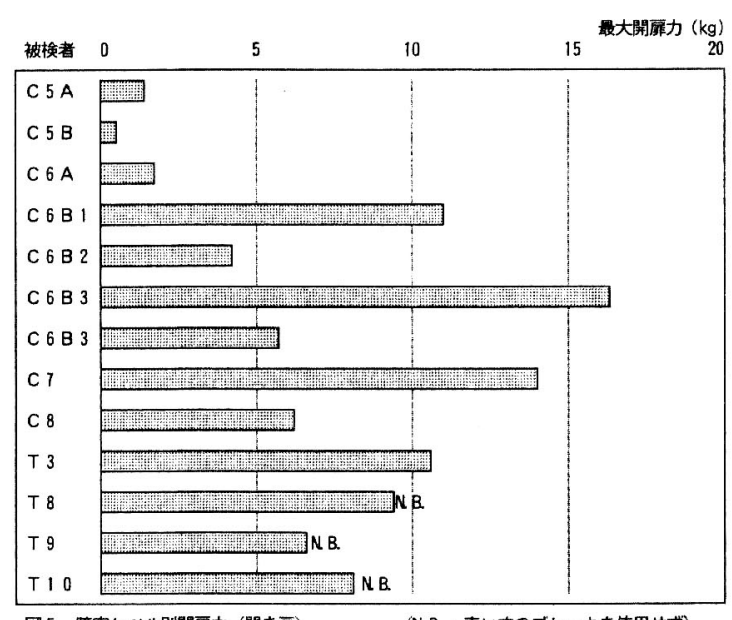

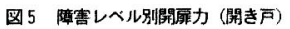

(N B. : 車いすのブレーキを使用せず)

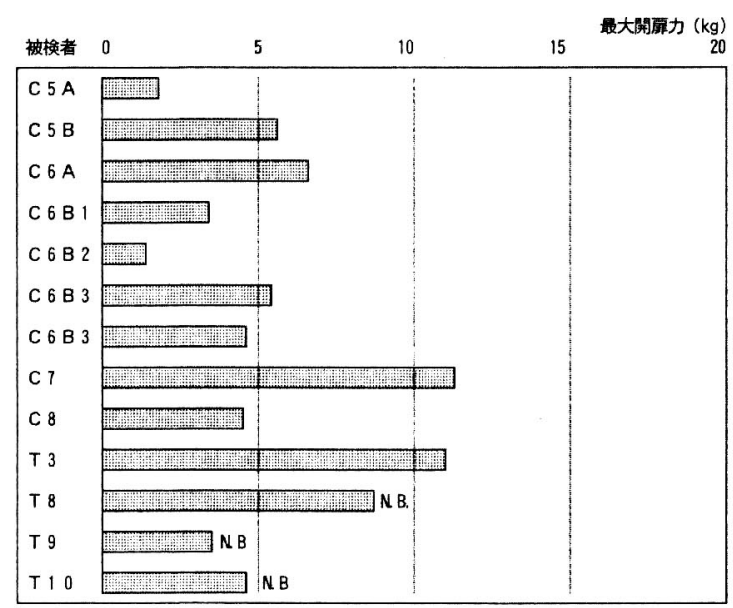

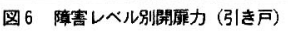

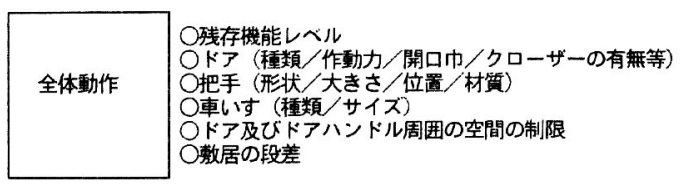

トアに近づく ○車いすの走行操作方法及び力（前進／後退／旋回／制動) ○アプローチまでの動作空間の制限

\begin{tabular}{|c|c|}
\hline ドアに接する & $\begin{array}{l}\text { ○トアへのアプローチ角度／近接位置 } \\
\text { (上肢の阵能、リーチ、車いすの゙、座位姿勢) }\end{array}$ \\
\hline
\end{tabular}

手や时を伸ばす

○上肢・体幹の角度

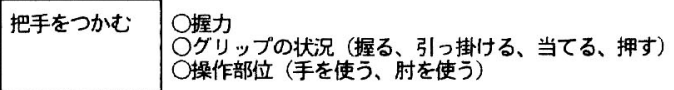

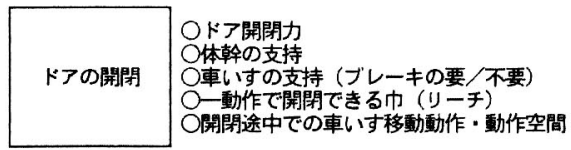

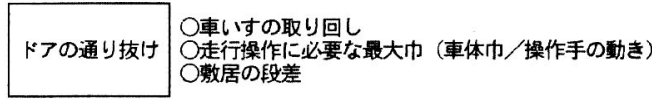

図2出入口の通り拔けに関わる要因

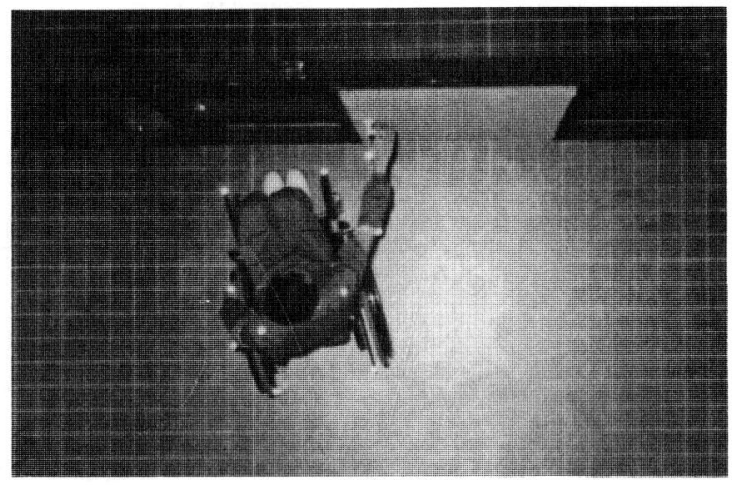

図3開き戸へのアプローチ(T10)

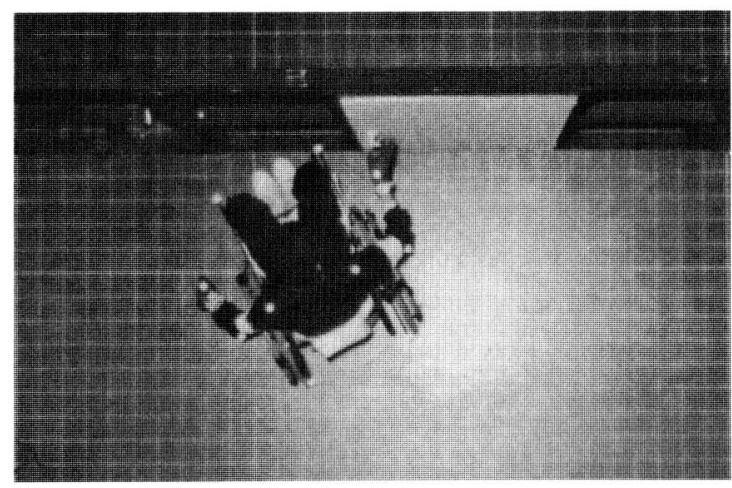

图4 開き戸へのアプローチ (C5B) 